\title{
EXPLORING TRAUMA AND HOPE IN REFUGEES' POEMS
}

\author{
Nur Amalina Roslim, Nur Syasya Qistina Mazeree, \\ Tao Jiajin, Emily Lau Kui-Ling \\ Universiti Malaya, Kuala Lumpur, Malaysia \\ E-mail: elkl@um.edu.my
}

Received: 2021-04-26

Accepted: 2021-06-02

\begin{abstract}
A situation of enforced migration in which individuals are compelled to migrate against their own causes a sense of displacement (Shamsuddoha et al., 2012). As of 2019, UNHCR has confirmed a population of 79.5 million forcibly displaced refugees, which accounts for nearly one percent of the global population. Displaced refugees is a topic that has gained international focus in numerous disciplines - anthropography, geopolitics, health sciences, to name a few. This paper examines displaced refugees through two recent poems composed in 2018: Greetings to the People of Europe by Alemu Tebeje and When Exile Comes: How the Brain Reacts to Trauma by Eric Ngalle Charles. Both poets have lived as refugees, and they both have experienced displacement and consequently, its hardships. It aims to provide a linguistic lens in analysing displaced refugees' plights by identifying and foregrounding distinctive linguistic devices in the poems. The in-depth stylistic analysis of the poems unveils that, while trauma is commonly discovered, hope and future viewpoints are equally registered.
\end{abstract}

Keywords: displacement; refugee; linguistic devices; hope; trauma; stylistic analysis.

\section{Introduction}

Displacement is a human behaviour of enforced nature; currently on the rise globally mainly because of political conflicts and natural disasters (Siriwardhana \& Stewart, 2013). Conflicts of war and persecution generally lead to either people being displaced within the country or escaping to other countries (Ferris, 2008). Refugees flee from homeland to seek asylum in other countries. As of 2019, United Nations High Commissions for Refugees (henceforth, UNHCR) has confirmed approximately 79.5 million forcibly displaced refugees. Refugee Convention (1954) defines "refugee" as a person who, "owing to well-founded fear of being persecuted for reasons of race, religion, nationality, membership of a particular social group or political opinion, is outside the country of his nationality and is unable or, owing to such fear, is unwilling to avail himself of the protection of that country" (as quoted in Ferris, 2008: 77).

Many studies have so far investigated some adverse impacts of displacement on mental health, inclusive of depression, anxiety, violence, post-traumatic stress disorder (henceforth, PTSD), and so forth (Bhugra \& Jones, 2001; Horn, 2010; Amirthalingam \& Lakshman, 2013). Moreover, it is argued that the displaced population continues to confront substantial stressors, such as problems with food, healthcare, employability, and discrimination, all of which may further promote mental disorders. 
Exploring Trauma and Hope in Refugees' Poems, Nur Amalina Roslim, Nur Syasya Qistina Mazeree, Tao Jiajin, Emily Lau Kui-Ling

In this paper, the impacts of displacement can be disclosed in poems by two selected poets, Alemu Tebeje ("Greetings to the People of Europe") and Eric Ngalle Charles ("When Exile Comes: How the Brain Reacts to Trauma"). The following synopsis of both poems describes the situations faced by displaced refugees. The poem, "Greetings to the People of Europe" (henceforth, "Greetings") is a portrait of the displaced persona in exile in the hope of seeking help from one of the first world countries, Europe. Tebeje is an Ethiopian journalist, and he recalls how brutal and inhumane his home regime was to its people. In this context, the poet recalled the teaching of love from European missionaries to the forefathers of his nation. Inspired by such teaching, the poet endured unimaginable sufferings within his nation alongside the extremely harsh conditions on his way to Europe. It can be inferred from the poem that the poet firmly believes that the Europeans "all the lovely words" (line 19) that they preached to the forefathers of the author.

The other poem, "When Exile Comes: How the Brain Reacts to Trauma" (henceforth, "When Exile Comes") is a vivid reflection of the displaced life of the poet Ngalle who was a Cameroonian refugee who writes extensively about displacement and the arduous journey of seeking refuge. First and foremost, Ngalle went through the loss of identity when he prayed in a tongue he did not understand since prayer is usually an intimate manner of communication that is often delivered in one's mother tongue. Subsequently, he expresses extreme solitude by living as a stranger in a foreign land. He presented life difficulties, such as paying debts and having holes in his shoes. In this context, the poet has "cried" and "laughed," and he eventually was waiting to be buried - reflecting the likeliness of mental distress and the loss of hope.

\section{Literature Review}

In this section, this paper reviews some key literature on displacement and the impact of displacement on refugees. The recent years witnessed an upsurge of refugee populations worldwide. Although refugees' physical needs are attended to by many organizations like the World Health Organization (WHO) and the UNHCR by providing food and shelter, the delicate matter of mental health of the refugees is not receiving proper attention, chiefly because the inequitable refugee service distribution together with difficulties in coordinating such services across borders (Silove, Ventevogel \& Rees, 2017). Due to the distressing and traumatic events faced by the displaced refugees, it is discovered that some of them have endured psychological effects such as PTSD. It is noteworthy that both poems are distinctive in revealing and expressing psychosocial duress of the displaced personas. Therefore, the linguistics analyses will tie in the manifestations from feelings of being overwhelmed, fearful and/or helpless.

\subsection{Displacement}

The last one hundred years have been called as an era of unprecedented displacements in many senses - from witnessing the flood of rural populations to metropolis, the diasporas of migrant workers to mass refugees' exodus (Smith, 2007). In poetry, the theme of displacement is largely deployed to represent poets' senses of personal estrangement and their existential angsts with their unsettling, uprooted conditions. Refugee movement and human displacement have been one of the consequences of conflict within a country and between societies. Despite the popular perception of the refugee movement and human 
displacement as phenomena that have seen marked upturns in recent years, it is still debatable whether there have been qualitative changes in patterns of forced displacement over the past century (Newman \& Van Selm, 2016: 3). This paper focuses on two displaced African refugee poets who have left their homeland and migrated to Europe. According to Ngalle, he states that he had lost the concept of a home completely considering the hardships he had gone through: he had slept on tree trunks, tree branches, used stones as a substitute for pillows (Migrant Offshore Aid Station, 2017). Based on the statistics, the peak of forced exile was the spring of 1992, when 356, 627 persons had to flee from their homes (Ajdukovic \& Ajdukovic, 1998: 187). According to the Office for Displaced People and Refugee (1997), by October 1997, there were still 287366 people that remained displaced and/or had refugee status (cited in Ajdukovic \& Ajdukovic, 1998: 187).

\subsection{Trauma and Hope in Displaced Refugees}

A wide range of studies have investigated physical losses and adverse mental issues found amongst displaced refugees. Displaced refugees face a wide range of losses: from the comfort of their homes, familiar environment where they grew up, educational settings, social network to living patterns with their loved and closed ones. The home itself plays a crucial role in the identity formation and development of children (Ajdukovic \& Ajdukovic, 1998: 187). Losing these crucial aspects of life clearly had negatively impacted the individuals involved, physically or mentally. As what has been reflected in the title of Ngalle's poem, "When Exile Comes", Ngalle described his hardships of being a displaced refugee, and somehow it has traumatized and impacted him physically and mentally. Being traumatized by what happened, Ngalle stated that it was and still an absolute and lonely experience to him as all he carried with him was his memory, mental and physical scars (MOAS, 2017). Studies suggest that during warfare, displaced adults frequently display anxiety, depression, anger, aggression, alcohol abuse, distrust, somatization or 'escape to illness,' and sleep disturbance (Moro \& Vidovic, 1992 as cited in Ajdukovic \& Ajdukovic, 1998: 187). Along the displacement process, it has made the refugees feel traumatized, degraded, demotivated, demoralized and become financially dependent, hopeful and helpless.

Based on the previous study conducted by Ajdukovic and Ajdukovic (1998), the findings revealed the mother's perceptions on the stress reaction of displaced children. The mothers stated that exposure to living in displacement is likely to result in a number of stress-related symptoms (McCallin \& Fozzard, 1990; Ressler et al., 1988 cited in Ajdukovic \& Ajdukovic, 1998: 190). Another statement from the mother's perception taken from the study, displacement had a strong negative impact on the children's well-being (Ajdukovic \& Ajdukovic, 1998: 190). In the same study, the findings found that the depression score for refugee children was significantly high. It also disclosed that the importance of the family and the support it provides to a child in coping with the prolonged stressful situation of displacement (Ajdukovic \& Ajdukovic, 1998: 193). However, based on Ngalle's poem, he clearly lost one of the most essential aspects - his family.

Parents or caregivers play a very crucial role in protecting the children's health, physically and mentally. Developing effective interventions to help parents on how to do parenting effectively within a new context can reduce refugee families' suffering throughout their journey to resettlement, and it should be a global mental health priority (UNICEF, 2013; Williams, 2012 cited in El-Khani et al., 2016: 99). A recent review conducted by Hassan, 
Exploring Trauma and Hope in Refugees' Poems, Nur Amalina Roslim, Nur Syasya Qistina Mazeree, Tao Jiajin, Emily Lau Kui-Ling

Ventevogel, Jefee-Bahloul, Barkil-Oteo, and Kirmayer (2016) emphasizes the importance of formulating mental health difficulties in non-stigmatising and inclusive ways that avoid labelling and acknowledge the multiple casualties of these, including stress-induced exacerbations of pre-existing conditions, problems arising from the experience of violence and conflict, and difficulties arising from adaptation to new contexts through conflict and displacement (as cited in El-Khani et al., 2016: 100).

\section{Research Method}

This present study is a qualitative research where a linguistic analysis of two poems entitled, 'Greetings to the People of Europe!' by Alemu Tebeje and 'When Exile Comes: How the Brain Reacts to Trauma' by Eric Ngalle are analysed by drawing out the sense of displacement by examining what linguistic features re being foregrounded in the two poems. In a linguistic context, this type of analysis deals with a wide variety of linguistic features and studies the ways in which language is used in literary works and the implementations are descriptive where all findings are descriptively explained. It is grounded under the umbrella of stylistics. Stylistics is widely known as a branch of applied linguistics which is concerned with the study of style in language in both literary and non-literary texts (Jeffries \& Mclntyre, 2010; Jandlová, 2018). Using a stylistics approach is a systematic way which provide objective and scientific commentary on the data. Researchers used this approach to closely analyse literary or non-literary texts by looking at the various levels. Since every author has his or her own distinct unique style in writing, this field is adopted as a tool to explore their choice of linguistic means which illustrate the relationship between the words used and the functional significance (Hough, 2019).

In the case of poetry, a poem in particular, "is realized by lines, stanza, and sub-stanza" where the meaning of the poem will be understood by relating each part that is "bound together" to form the poem. Stylistics analysis of a poem can show how poetic style creates meanings and effects (Rifqi, 2009). It is not only about the poet's style, but how the poet chooses certain patterns in a stanza, for instance, can be used as linguistic evidence to interpret the possible meaning/s in a poem. It is important to have knowledge of how the language itself works in order to foreground the irregularity of the linguistic features that are manifested in the text. The foregrounding of the linguistic features can be achieved through the presence of linguistic deviation, parallelism, and repetition (Leech, 2014). The significant functions of the foregrounded features will help in integrating the meaning in a poem. By using stylistics approach, the purpose of the language use and its effects can be uncovered. In the same vein, it is the very method that will be employed to disclose the sense of trauma and hope amongst the refugees in both the poems, "Greetings" and "When Exile Comes".

\subsection{Data}

Poetry and prose written on the theme of "displacement" are popular among the literary works and writings of refugees. The written work of refugees about their experiences can be found in several online platforms including the Exiled Writers Ink and the Migrant Offshore Aid Station (henceforth, MOAS) websites. During the annual refugee week, the arts and works of people experiencing forced displacement are published on these online platforms (Catrambone, 2019; Langer, 2019). The selection of the poem begins with a few criteria: keywords search (refugee, poetry, and displacement); time frame (within the last 
five years); and medium (unpublished, freely available on the internet). The final selection is made up of poems that receive little attention, self-composed on the Internet, and express the life of refugees that is replete with hardships. The poems used for this analysis were focused on refugees' sentiments related to hope and trauma in their poetry. Both poets wrote the poems based on their own life story which makes it more personal and easier to comprehend with the help of additional reading on their background information. These poems registered the sense of displacement in two conflicting different ways: trauma and hope; pithily portrayed by both personas.

The poem, "Greetings" focuses on the displacement persona felt as a refugee. This poem vividly portrays how refugees always seek help with hope in their hearts that there would be someone who would take them one day. In the first line, the persona describes how the European come to Africa in two ways: land and sea. In line 2, the persona continues to unveil the European's mission in which they unload enormous number of bibles in order to share the words of love from the bible to the persona's forefathers. As seen in lines 4-7, verses taken from the bible are referred to inculcate refusal to vengeance and revenge in favour of forgiveness and loving others, including your enemies. Next, the persona continues by representing himself as one of the forefather's generation to preach the words of love that the Europeans have passed down years ago (lines 8-9). In lines 10-11, the persona describes their hardships and unfortunate fate of being displaced by giving an imagery of the actions faced; slapped and stripped in their home country. Lines 12-13 explain the challenging journey of the displaced persona en route Europe to seek for help and this line discloses the hardships that the persona faces during the journey and how fearful he is to face the calamities. After describing the hardships of his journey at the sea, the persona continues in lines 14-15 to express his hope and willingness to survive the challenges and difficulties in the journey to Europe. The words of love give them hope, enabling them to suffer persecution and seek refuge with the innocent and genuine hope of being adopted by those loving Europeans whose forefathers preach "words of love." In lines 16-17, the persona describes his successful arrival to Europe. Lastly, in lines 18-19, the persona remains optimistic and hopeful that he will be able to resettle with the assistance of the Europeans.

On the contrary, the poem, "When Exile Comes" focuses more on hopelessness due to the displaced experiences undergone as a refugee, where all the hardships lead the persona to feel like he desires to die. The persona feels displaced in a new place where he is not familiar with. The persona's feeling of being in a strange place is clearly depicted by language barrier where he prays in a language that he does not speak. He feels helpless and there is nothing that he can do but to mockingly laugh at himself. Furthermore, the time spent by persona roaming to seek a home or permanent shelter is long and this is portrayed in his words, "[m]y wrinkles hiding the passage of time" (line 6). After spending a long time seeking for shelter, the persona is given a new beginning as a refugee in a place far from home. However, he is still haunted by his past. This feeling is portrayed in line 7 where he feels like he is a stranger among the people in a community. In this new home that he finds refuge, he does not seem to find hope and is constantly troubled by his past. This feeling of hopelessness is clearly depicted from lines 9 to 16 . The helplessness that he experiences is causing him to lose hope in life. Lastly, lines 17-19 arrive at a point of climax of hopelessness, in which the author repeatedly says, "this is my grave", which veers into morbidity where the persona hopes that death can finally terminate his suffering. This thought further 
Exploring Trauma and Hope in Refugees' Poems, Nur Amalina Roslim, Nur Syasya Qistina Mazeree, Tao Jiajin, Emily Lau Kui-Ling

clarifies the displacement and hopelessness experienced by the persona as a refugee in a whole new place far from his home.

With the opposite sense of hope registered by both personas in the above poems, their position as displaced refugees - both poems disclose insights to refugees' experiences and predicaments.

\subsection{Procedure}

This analysis was carried out by following the heuristic checklist of linguistics and stylistics categories presented by Leech (2007). This checklist provides a 'systematic basis' for the collection of relevant linguistic data from the text for the purpose of stylistic evaluation and offers four levels for analyzing the linguistic choices made by the writer, in terms of style. These levels include the lexical categories, grammatical categories, figures of speech and context and cohesion". Leech (2007) points out that while the list itself is a selective one, leaving out a lot of detail but it allows the reader to reach the significant and relevant features of the text through a linguistic survey.

By utilizing stylistic analysis, this paper explores the trauma and hope portrayed in the two poems by examining the foregrounding of grammatical categories, figure of speech, and graphological deviation. In terms of grammatical categories, repetition of certain lexical items and paralleled structure that are foregrounded are selected for analysis. Additionally, figure of speech, specifically hyperbole, is also taken into consideration. A visual feature, graphology, though not listed in this heuristic checklist, is incorporated in the analysis due to its prominent role. All these features are analysed thoroughly by relating them to traumaand hope-related sentiments. Concurrently, the poets' background information is alluded to as they project their angsts through their poetry. The analysis maps out both poems to vividly provide an insight on how linguistic features that are foregrounded in the poems can function as a means that reflect the sense of hope and trauma by both poets.

It is observed that both poems have unique spacing style: "line-by-line arrangement of the poem on the page with irregular margins" (Pirnajmuddin \& Medhat, 2011: 1331). Therefore, reference to lines rather than stanzas within the analysis can avert any confusion in the positioning of the content and respect the unique construction of both poems. Following this, both poems are labelled according to lines throughout the whole paper.

\section{Results and Discussion}

In both poems, hope-related sentiments are implied through various linguistic features. By studying stylistics of poems, literary meanings and structural features can be decoded for better comprehension (Ferdows \& Masoud, 2012). This literary analysis utilizes stylistics analysis to identify and label foregrounded linguistic features, analyze systematically features, inter alia, repetition, hyperbole, parallelism and graphological deviation. Foregrounded linguistic features in both poems are closely examined to reveal juxtaposition of hope-related sentiments, namely, hopefulness and hopelessness. A close investigation of the ways Alemu Tebeje Aleye, the poet of "Greetings", and Eric Ngalle Charles, the poet of "When Exile Comes" react to displacement is done. 
Greetings to the People of Europe!

by Alemu Tebeje Aleye (2018)

\begin{tabular}{|c|c|}
\hline $\begin{array}{l}\text { Line } 1 \\
\text { Line } 2 \\
\text { Line } 3\end{array}$ & $\begin{array}{l}\text { Over land and sea, your fathers came to Africa } \\
\text { and unpacked bibles by the thousand, } \\
\text { filling our ancestors with words of love: }\end{array}$ \\
\hline $\begin{array}{l}\text { Line } 4 \\
\text { Line } 5 \\
\text { Line } 6 \\
\text { Line } 7\end{array}$ & $\begin{array}{l}\text { if someone slaps your right cheek, } \\
\text { let him slap your left cheek too! } \\
\text { if someone takes your coat, } \\
\text { let him have your trousers too! }\end{array}$ \\
\hline $\begin{array}{l}\text { Line } 8 \\
\text { Line } 9 \\
\text { Line } 10 \\
\text { Line } 11\end{array}$ & $\begin{array}{l}\text { now we, their children's children, } \\
\text { inheriting the words your fathers left behind, } \\
\text { our bodies slapped and stripped } \\
\text { by our lifetime presidents, }\end{array}$ \\
\hline $\begin{array}{l}\text { Line } 12 \\
\text { Line } 13 \\
\text { Line } 14 \\
\text { Line } 15\end{array}$ & $\begin{array}{l}\text { are braving seas and leaky boats, } \\
\text { cold waves of fear - let salt winds punch } \\
\text { our faces and your coast-guards } \\
\text { pluck us from the water like oily birds! }\end{array}$ \\
\hline $\begin{array}{l}\text { Line } 16 \\
\text { Line } 17 \\
\text { Line } 18 \\
\text { Line } 19\end{array}$ & $\begin{array}{l}\text { but here we are at last to knock } \\
\text { at your front door, } \\
\text { hoping against hope that you remember } \\
\text { all the lovely words your fathers preached to ours }\end{array}$ \\
\hline
\end{tabular}

Figure 1: "Greetings"

\begin{tabular}{|c|c|}
\hline Line 1 & That day, I prayed in a tongue \\
\hline Line 2 & I did not understand, \\
\hline Line 3 & In a language, I did not speak. \\
\hline Line 4 & I laugh. \\
\hline Line 5 & Rain bouncing on my back, \\
\hline $\begin{array}{l}\text { Line } 6 \\
\text { Line } 7\end{array}$ & $\begin{array}{l}\text { My wrinkles hiding the passage of time, } \\
\text { Living as a stranger amongst my own. }\end{array}$ \\
\hline Line 8 & I cry. \\
\hline Line 9 & I do not remember my dreams, \\
\hline Line 10 & the sun rays avoid my skin. \\
\hline Line 11 & My shoes have holes. \\
\hline Line 12 & I paid my debts a thousand times \\
\hline Line 13 & to those who planned to kill me. \\
\hline Line 14 & I laugh. \\
\hline $\begin{array}{l}\text { Line } 15 \\
\text { Line } 16\end{array}$ & $\begin{array}{l}\text { This is my grave, } \\
\text { This is my grave }\end{array}$ \\
\hline Line 17 & I stand in a field of Daffodil \\
\hline Line 18 & I am Waiting for you, \\
\hline Line 19 & I am Waiting for you to bury me. \\
\hline
\end{tabular}

Figure 2: "When Exile Comes". 
Exploring Trauma and Hope in Refugees' Poems, Nur Amalina Roslim, Nur Syasya Qistina Mazeree, Tao Jiajin, Emily Lau Kui-Ling

The poem, "Greetings" specifically portrays hopefulness as displaced refugees hopefully seek help from Europe as seen in lines 12-15.

Table 1: Lines that indicate Hopefulness

Line $12 \quad$ are braving seas and leaking boats

Line $13 \quad$ cold waves of fear - let salts wind punch

Line $14 \quad$ our faces and your coast-guards

Line $15 \quad$ pluck us from the water like oily birds!

Lines 12 to 15 describe the journey of the displaced persona heading to Europe to reach for help. Line 12 portrays the hardship he faces throughout the journey. Despite tempestuous seas' conditions and leaky boats, he then says in lines 14-15 that, "coastguards/ pluck us from the water like oily birds!". This is the hope for the poet who strives to survive the odds in the arduous journey of escaping from his homeland turmoil. In line 13, "let salt winds punch" shows how persona expresses his fearful emotions yet striving to survive. In reality, no one would allow oneself to be punched but persona is willing to be in pain to seek help because he is vulnerable and hopes to be saved.

As for the poem, "When Exile Comes", the overarching theme is that of hopelessness. Ngalle, the poet, informs that he suffers hardships in life and is betrayed by his father's family when he is in Cameroon (MOAS, 2017). This reality leaves a deep wound in him and contributes to his feeling of hopelessness. Likewise, as reflected in the poem, the persona experiences hardships and desperation because he "lives as a stranger among my own" and even "sun rays avoid my skin". Consequently, from lines 15-19, the persona expresses his hopelessness that although he stands on a field of daffodil, a symbol of hope and rebirth, he is "waiting for you to bury me". This contradictory expression intensifies his hopelessness. All he could see is his own open grave (lines 15-16, "This is my grave"). Therefore, the poet's experience of betrayal from his family takes a heavy blow on him and this very experience is cast upon the persona's ominous sense of hopelessness.

The first similar linguistic feature in both poems is repetition of the words; 'love' and 'words' that express the themes of hopefulness and hopelessness. Repetition is commonly used in literary texts to produce deeper emphasis, clarity, and amplify the emotional effects (Ochoa, 2014). In "Greetings", the lexis "words" is repeated three times throughout the short poem - "words of love", "words your fathers left behind", and "lovely words" (lines 3, 9 and 19).

Table 2: Example of Repetition in "Greetings"

\begin{tabular}{ll}
\hline Line 3 & filling our ancestors with words of love: \\
Line 9 & inheriting the words your fathers left behind, \\
Line 19 & all the lovely words you father preached to ours. \\
\hline
\end{tabular}

This repetition is to describe 3 different stages that "words" have impacted Africans' life. The phrase in line 3, "words of love" is not only preached, but also inherited and deeply rooted in the lives and hearts of these Africans. It is derived from Bible verse that Tebeje includes as a part of the poem itself in lines 4-7. The Bible verse; "if someone slaps your right cheek, let him slap your left cheek too! If someone takes your coat, let him have your trousers too!" is said to be the rejection of revenge and retaliation and focusing on forgiveness and loving others, even your enemies. In line 3, the first repetition of "words" alongside the first polyptoton "love' is to describe Europeans preaching "words of love" and kindness to Africans. 
While in line 9, it refers to how Africans inherit and nurture "words of love" in their life. Lastly, "lovely words" in line 19 show that these Africans are now hoping for Europeans to remember the words of love that they preach before. The polyptoton of "love" is used as adjectives, 'lovely' to depict a clearer image of what type of words that the Europeans preach to them. Lewis (2020) explains that using adjectives in poetry allows the poet to give readers a clearer picture of what the poet is trying to say. The Africans hope that the European would remember the love and kindness they teach and gospelize them. Thus, repeating "word" and the polyptoton of "love" shows the importance of the words of love that Africans now live by. The hopefulness that they have in their life despite hardships and struggles that they face attribute to these words of love.

Contrarily, "When Exile Comes". repeats the phrase "This is my grave" (lines 15-16) to reflect sense of hopelessness. In this poem, Ngalle describes how he is treated by society as a refugee. He spends years of his life seeking for a new place he could call home (MOAS, 2017). It can be seen in lines 1-3 that he tries so hard to have a better life where he wrote, "I prayed in a tongue I did not understand, in a language, I did not speak". These lines show his desperation to ask for God's help to have a better life because he is now using a language that is not his language. Baesler (2003) defines prayer as an intimate spiritual communication between a believer and God. Prayer is an intimate action that creates a bond between humans and God where people would try to communicate as comfortably as they could. However, this poem shows persona's desperation for him to start praying in an unfamiliar language. Those hardships including "[I]iving as a stranger amongst my own" (line 7) has led him to feel hopeless in life. He is also living in a situation where his life could be ended anytime by "those who planned to kill me" (line 13). Consequently, he feels hopeless to find a reason to continue seeking for a new home. The phrase "[t]his is my grave" which is repeated twice emphasizes how the persona has now lost hope in continuing his journey. He has determined that it is hopeless to find a home except for this "grave" which might be the end of his journey in finding a place to call home. The determiner "this" is used to refer to something or somewhere near to the speaker and in this phrase, it is referring to the place that he is currently at. The noun "grave" indicates where all ends for the persona.

He shares his thoughts on his journey by mentioning that moving from one country to another as refugee, climbing mountains, crossing seas, seeking peace, and finding none, has forced him to be in a state of hopelessness. Thus, the repetition of, "[t]his is my grave" in lines 15 and 16 emphasizes the emotion he feels when he decides to end the hopeless search for a new place to live. In sum, these all relate to deeply rooted hopelessness of the persona's life.

The next linguistic feature foregrounded in the poems is hyperbole. Hyperbole is "exaggerated intensification, expanding or enlarging of an entity and the exaggerated reduction or attenuation" (McCarthy \& Carter, 2004, p. 151). Both poems use hyperbole to reveal hope-related sentiments. Nevertheless, by using the same linguistic device, they reveal contrasting hope-related sentiments. "Greetings" is about hopefulness whilst "When Exile Comes" is about hopelessness.

For "Greetings", the example of hyperbole can be found in line 2 . The phrase "by the thousand" is meant to exaggerate and intensify. This is to create a maximum effect of the "words of love" that Europeans preached to Africans. It also refers to the abundance of words of love that is preached, and it implies that these give Africans a faith and belief by teaching them love. Subsequently, the Africans have learnt words of love, what and how to practice it. This superlative form of love is then reflected upon from lines 4-7 in details. The 
Exploring Trauma and Hope in Refugees' Poems, Nur Amalina Roslim, Nur Syasya Qistina Mazeree, Tao Jiajin, Emily Lau Kui-Ling

use of hyperbole then reflects the theme of displacement. Albeit hardships and sufferings of displacement, the abundant amount of "words of love" blessed displaces Africans who face unfortunate fate at home, in that their bodies are "slapped and stripped". Moreover, words of love give them hope to endure injustice and seek asylum with innocent and sincere hopefulness that they will be adopted by those loving Europeans whose forefathers preach "words of love". In sum, using hyperbole reflects hopefulness amongst displaced African refugees seeking asylum in Europe.

In "When Exile Comes", the example of hyperbole can be seen in line 12. It is generally challenging to count times of paying debts, so "[a] thousand times" is an extravagant exaggeration to disclose that the refugee pays loads of debts repeatedly for many times and the overwhelm emotions and feelings of doing so. The use of hyperbole releases compelling effects. The repetition of paying debts can cause lots of mental pressure to the persona, and it aligns with "how the brain reacts to trauma" in the title. In the context, the persona feels he is forsaken, isolated and shunned as he says even "the sun rays avoid my skin". Haunted by such traumatic memories, the persona repeatedly pays debts to "those who plan to kill $m e^{\prime \prime}$. This appears that the persona is in an inferior social status and his life is under threat. Those in his new community who not only unwelcome him but also be hostile to him in that he is a refugee and is of lower social status. This has led to the persona to feel mentally exhausted. He has had enough of this and could not bear more. By repeatedly paying debts, the persona lingers on in a steadily worsening condition as a displaced refugee. The use of hyperbole correlates to the conflicting sense of hope and trauma endured by the persona. These all reflect extreme traumatic hopelessness that is deeply embedded in the bottom of the persona's heart. To sum, the persona could do nothing about steadily spirals into hopelessness.

The next linguistic feature found in both poems is parallelism. In "Greetings", lines 4-7 derive from Bible verses reflecting the words of love. The verses are taken from the Bible but some words have been substituted by the poet parallelly. In addition to that, it is also to show that two or more ideas have the same level of importance. These lines portray the main points of words of love that are passed by the European to the Africans. This verse has been modified into a parallel sentence structure as the poet intends to emphasize how powerful this Bible verse is in the Africans' lives. This verse has built faith in the Africans' lives which lead them to have hope in receiving "words of love" by the Europeans. The sentence structure of these lines remains the same but the verbs and nouns of the lines are changed. The changes could be seen in Tables 1 and 2 below.

Table 3: Paralleled Sentence Structure in "Greetings"

\begin{tabular}{lllll}
\hline Conjunction & Pronoun & Verb & Pronoun & Noun \\
\hline if & someone & slaps & your & right cheek \\
if & someone & takes & your & coat \\
\hline
\end{tabular}

Table 4: Paralleled Sentence Structure in "Greetings"

\begin{tabular}{|c|c|c|c|c|c|}
\hline Verb & $\begin{array}{l}\text { Object } \\
\text { Pronoun }\end{array}$ & Verb & $\begin{array}{l}\text { Possessive } \\
\text { Adjective } \\
\text { Pronoun }\end{array}$ & Pronoun & Noun \\
\hline let & him & slaps & your & $\begin{array}{l}\text { left } \\
\text { cheek }\end{array}$ & too! \\
\hline let & him & have & your & trousers & too! \\
\hline
\end{tabular}


The main verbs "slaps" and "takes" are enforcing actions, whilst nouns "coat" and "trousers" are personal belongings. This could reflect the torture from their own regime, and yet, by the "words of love" abiding by their life, the Africans do not take revenge. The verb, "let" and auxiliary verb, "have" indicate actions of willingness. They willingly give their personal belongings. This is to clarify and reinforce the power of love on them and intense hope they have from "words of love" as an integral belief.

In the poem, "When Exile Comes", parallelism is seen in lines 4, 8 and 14 where a simple sentence is written to actualise the feeling of hopelessness that the poet feels. It is written in simple and short sentences, yet it brings a powerful meaning to the poem's context. The paralleled sentence structure is in the Table 5 below.

Table 5: Paralleled Sentence Structure in "When Exile Comes".

\begin{tabular}{ll}
\hline Subject (Pronoun) & Verb \\
\hline 1 & laugh \\
1 & cry \\
1 & laugh \\
\hline
\end{tabular}

The use of the verbs "laugh" and "cry" could be a kind of ironic yet sarcastic choice of word chosen by the persona to speak about his life. This also displays the persona suffering from a loss of identity and the frustration that follows. Therefore, the persona mocks himself by laughing. He feels helpless and there is nothing he can do but to laugh. The word "laugh" and "cry" are used in a paralleled structure which leads to the ironic situation even though they are mentioned in different lines. The title of the poem is "How the Brain Reacts to Trauma" so this has close relation with the mental state of the persona, who may have been traumatized because of displacement and living a life as a displaced refugee. In this regard, the trauma and mental disorders contribute to hopelessness. Being hopeless, one may become mentally unstable not knowing what to feel. Sometimes one feels sad and sometimes excited. Using parallelism of these simple sentences creates tension of unstable mentality and clarifies that the persona has been suffering from mental distress because of he feels futile.

Another similarity that can be found in both poems is the use of graphological deviation. However, this feature is used differently in terms of function in order to convey the meaning of the poems while disclosing the theme of the poem; hopefulness and hopelessness. Graphological deviation found in "Greetings" is the use of dash in line 13.

Table 6: Example of Graphological Deviation in "Greetings"

Line $13 \quad$ cold waves of fear - let salts wind punch

It can be observed that the poet uses dash to compound and link the "cold waves of fear" and "let salt winds punch" to represent an abrupt break bringing an impact to the meaning of this line. The dash's purpose is to indicate a sudden shift in a sentence or to set off and draw attention to specific words. The persona tries to portray that he has a short break deciding whether he wants to continue his journey seeking help. After thinking, he thinks that there is hope for him to seek and get the help he wants so he goes through the challenge, he willingly "let the salt winds punch" his face. Even though it is such a painful journey, he knows that he can survive or bear with it because he has hope to reach for help. In sum, this graphological deviation has helped to actualise the sense of hopefulness that the persona feels. 
Exploring Trauma and Hope in Refugees' Poems, Nur Amalina Roslim, Nur Syasya Qistina Mazeree, Tao Jiajin, Emily Lau Kui-Ling

As for "When Exile Comes", Ngalle uses two graphological features which are the deviation in the line arrangement and the capitalization of words. For the first deviation, it can be observed in the line arrangement of the poem which is graphologically odd. This is a type of deviation related to the poet's disregard of the rules of writing. "It is the line-by-line arrangement of the poem on the page with irregular margins" (Pirnajmuddin \& Medhat, 2011: 1331). By having an overall view of this poem, it can be seen that lines 4,8 and 14 are really short whereas line 6 and 7 and line 15 and 16 are about the same length. Looking at the context of "When Exile Comes", some lines are significantly short and some regularly matching lines as shown below:

Table 7. Example of Graphological Deviation in "When Exile Comes".

\begin{tabular}{ll}
\hline Line 4 & I laugh. \\
Line 8 & I cry. \\
Line 14 & I laugh. \\
Line 6 & My wrinkles hiding the passage of time, \\
Line 7 & Living as a stranger amongst my own. \\
Line 15 & This is my grave \\
Line 16 & This is my grave \\
\hline
\end{tabular}

Specifically, in lines 15 and 16, Ngalle repeatedly mentions '[t]his is my grave' in both lines which can be taken as a hint and be considered as a creative approach by the poet in revealing an idea of overall visual representation of this poem as shown in Figure 3 below.

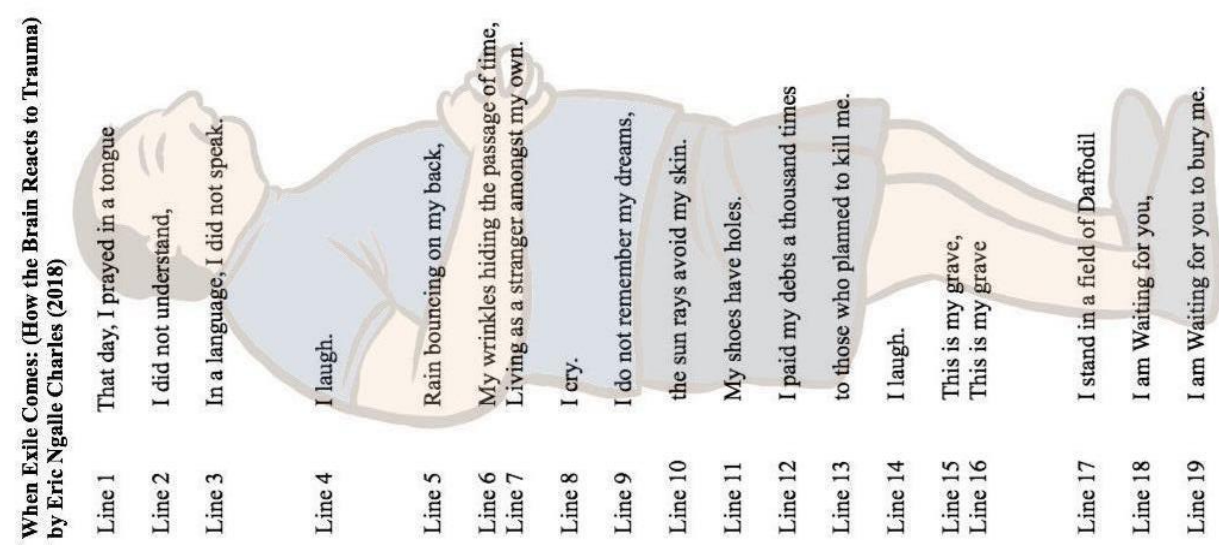

Figure 3: Visual Representation of "When Exile Comes"

"The graphological deviation or the special way of putting words and lines on the page may add some second meaning to the original meaning of the verse" (Pirnajmuddin \& Medhat, 2011: 1331). In these lines deviation has its own effect that evokes the second meaning related to the poem about hopelessness. After all the challenges and hardship, he is still overwhelmed with the feeling of fear that he could run no more and with the feeling of hopelessness, he feels the need to rest from the tiredness and exhaustion. This recalls back lines 18 and 19, 'I am Waiting for you,' and 'I am Waiting for you to bury me.' The effect evoked on the deviation of the line arrangement has clearly given an impact on how the readers could comprehend and get a gist by looking at the shape of the lines. The poet is hopelessly waiting for "you", the person who will find his corpse, and bury him. 
Another graphological deviation that can be found in "When Exile Comes" is the use of capitalization. In Lines 18 and 19, Ngalle inserts a capital letter in one of the words within the sentence.

Table 8: Example of Graphological Deviation in "When Exile Comes".

Line $18 \quad$ I am Waiting for you,

Line $19 \quad$ I am Waiting for you to bury me.

The letter ' $W$ ' in the word 'waiting' has been capitalized despite not being placed at the beginning of the sentence. This capitalization can be classified as initial word capitalization; the use of an uppercase letter in the initial position of a word. In "When Exile Comes", the poet intentionally capitalizes it to highlight the word 'waiting'. There are a few creative functions of capitalization, one of which is to emphasize certain elements in the poem. The effect evoked using initial capitalization in the word 'waiting' shows that the persona greatly suffers from the hardships he faces as a refugee that all he could do is to wait for someone to bury him; ultimately an utterance of his utter hopelessness.

\section{Conclusion}

In general, "Greetings" and "When Exile Comes" are both about displacement. They specifically disclose hope-related sentiments that are closely related with the hardships and trauma because of the personas' status as displaced refugees. Next, it is evident that similar linguistic features are found in both poems, such as repetition, hyperbole, parallelism, and graphological deviation. Analysing the poem stylistically also highlights how the most internally deviant features of the poem are those which we would usually consider to be 'normal,' non-deviant language in both everyday communication and within poetry, and suggests a reason as to why this might be. Stylistics, then, is helpful in explaining parts of a text which we might not otherwise understand (McIntyre, n.d.). These linguistic features foregrounded in the poems highlight the manifestation of trauma- and hope-related sentiments of the struggles faced by the personas. By utilizing these linguistic features, trauma- and hope-related sentiments are better comprehended and visualized.

Not surprisingly, different attitudes towards hope are discovered. It can be observed from previous analysis that both personas face similar traumas whereby they are forced to move to a new place, away from their homeland. They have to face challenges, mental and physical struggles. However, both personas show a bipolar views on hope despite facing similar traumas. In "Greetings", the persona is replete with hope. He is hoping that someone would save him from his situation and lead him to a better life. In most cases, the chance of refugees to be saved leading to a better life is relatively minimal. Phillips (2013) writes that "according to the UNHCR, less than 1 percent of the world's refugees may be resettled in any given year. Millions of refugees around the world continue to live with little hope of finding a solution to their plight..." (p. 5). Nevertheless, the persona of the poem "Greetings" is still optimistic and hopeful despite such minimal chance. He believes that he will be resettled by the helping hands of the Europeans. On the other hand, the persona of "When Exile Comes" showcases a strong sense of hopelessness that he is ready to give everything up including his life.

In a nutshell, the analyses on both poems are hoped to provide an opportunity to understand refugees' lives and help cultivate empathy towards their hardships and struggles for seeking a "normal" life. Based on the limited scope within our paper, some recommendations can be offered for enhancing future research. A development of 
Exploring Trauma and Hope in Refugees' Poems, Nur Amalina Roslim, Nur Syasya Qistina Mazeree, Tao Jiajin, Emily Lau Kui-Ling

methodology is suggested by expanding the sampling and the utilization of corpus-driven stylistics analysis. This will be more representative and generalizable. Recurring patterns and many other linguistics features, inter alia: phonological, point of view, semantic, deictic, may enable more grounded and multifaceted aspects of the refugee population to be captured as well. Besides, it is also commendable to triangulate stylistics analysis with ethnographic research as both will enrich and sharpen each other's observations.

\section{Acknowledgements}

The Principal Investigator wishes to convey appreciation to UM for the research funding under the grant: GPF006N-2018. The authors would also like to convey their sincere appreciation to one of the poets, Eric Ngalle Charles for responding to their queries through Syasya's Twitter and Instagram accounts.

\section{References}

Ajdukovic, M., \& Ajdukovic, D. (1998). Impact of Displacement on the Psychological Wellbeing of Refugee Children. International Review of Psychiatry, 10, 186-195.

Amirthalingam, K.; Lakshman, R. W. D. (2013). Impact of Displacement on Women and Female-headed Households: A Mixed Method Analysis with a Microeconomic Touch. Journal of Refugee Studies, 26(1), 26-46. Doi:10.1093/jrs/fes007

Baesler, E. (2003). Theoretical Explorations and Empirical Investigations of Communication and Prayer. Lewiston, NY: Edwin Mellen Press.

Bhugra, D., \& Jones, P. (2001). Migration and Mental Illness. Advances in Psychiatric Treatment, 7(3), 216-222. Doi:10.1192/apt.7.3.216

Cambridge International Dictionary of English. (1995). Cambridge: Cambridge University Press.

Catrambone, C. (n.d.). MOAS | Migrant Offshore Aid Station. Retrieved 29 May 2019, from MOAS I Migrant Offshore Aid Station website: https://www.moas.eu/Dyk, C. V. (2019). Dashes: Lessons on Punctuation. Retrieved July 02, 2020, from

https://natureofwriting.com/courses/punctuation/lessons/dashes/topic/how-to-usea- dash/

El-Khani, A., Ulph, F., Peters, S., \& Calam, R. (2016). Syria: The Challenges of Parenting in Refugee Situations of Immediate Displacement. Syria: The Challenges of Parenting in Refugee Situations of Immediate Displacement, 14(2), 99-113.

Ferdows, A. and Masoud, D. (2012). Stylistics and Linguistic Variations in Forough Farrokhzad's Poems. Journal of Language Teaching and Research, 3(5), 930-939.

Ferris, E. (2008). Internal Displacement and the Right to Seek Asylum. Refugee Survey $\begin{array}{lllll}\text { Quarterly, } & 27 & \text { (3): } & 76-92 . & \text { Doi: }\end{array}$ https://doiorg.ezproxy.um.edu.my/10.1093/rsq/hdn046 Gómez-Jiménez, E. M. (2017). 'nearer and nearer and NEARER': Foregrounding effects of the unconventional capitalization in the experimental poetry of E. E. Cummings. Journal of Literary Semantics, 46(2), 109-129. Doi: 10.1515/jls-2017-0007

Horn, R. (2010). Exploring the Impact of Displacement and Encampment on Domestic Violence in Kakuma Refugee Camp. Journal of Refugee Studies, 23(3), 356-376. Doi:10.1093/jrs/feq020

Hough, G. (2019). Routledge Revivals: Style and Stylistics (1969) (1st ed.). London: Routledge. 
Jandlová, P. (2018). A Comparative Stylistic Analysis of Original English Legal Texts and their Czech Equivalents (Unpublished doctoral dissertation). Masaryk University in Brno.

Jeffries, L., \& Mclntyre, D. (2010). Cambridge Textbooks in Linguistics in Stylistics. United Kingdom: Cambridge University Press.

Langer, J. (n.d.). Exiled Writers Ink. Retrieved 29 May 2019, from Exiled Writers Ink website: https://www.exiledwriters.co.uk/

Leech, G. (2007). Language in Literature: Style and Foregrounding. London: Routledge.

Lewis, T. (n.d.). Adjectives in Poetry. Retrieved July 01, 2020, from https://www.familyfriendpoems.com/poem/article-adjectives-in-poetry

McCarthy, M., \& Carter, R. (2004). There's Millions of Them: Hyperbole in Everyday Conversation. Journal of Pragmatics, 36(2), 149-184.

McIntyre, D. (n.d.). An Example of a Stylistic Analysis. Retrieved July 02,2020, from https://www.lancaster.ac.uk/fass/projects/stylistics/sa1/example.htm

Migrant Offshore Aid Station. (2017). My Story: Eric Ngalle Charles. Retrieved July

02 , 2020, from https://www.moas.eu/story-eric-ngalle-charles/

MOAS. (2017). My Story: Eric Ngalle Charles Retrieved February 08, 2021, From https://www.moas.eu/story-eric-ngalle-charles/

Newman, E. \& van Selm, J. (2016). Refugees and Forced Displacement: International Security, Human Vulnerability, and the State. Tokyo: The United Nations University.

Ochoa, S. (2014). Repetition in Poetry: The Many Ways to Create Poetic Intensity. Retrieved July 01, 2020, from https://blog.udemy.com/repetition-in-poetry/

Pirnajmuddin, H., \& Medhat, V. (2011). Linguistic Deviation in Poetry Translation: An Investigation into the English Renderings of Shamlu's Verse. Journal of Language Teaching and Research, 2(6), 1329-1336. doi:10.4304/jltr.2.6.1329-1336

Phillips, J. (2013). Asylum Seekers and Refugees: What are the facts? Canberra: Department of Parliamentary Services, Parliament of Australia. Repetition in Poems: Examples \& Definition. (2015). Retrieved from https://study.com/academy/lesson/repetition-inpoems-examples-lesson-quiz.htm

Rifqi, M. (2009). Cohesion in Poem: A Case Study in Marks and the Way Things Are. LITE, 5 (1), 58-80.

Shamsuddoha, M. D., Khan, S. M. Munjurul Hannan, Raihan, S., \& Hossain, T. (2012). Displacement and Migration from Climate Hot-Spots in Bangladesh: Causes and Consequences. Bangladesh: ActionAid Bangladesh.

Siriwardhana, C. \& Stewart, R. (2013). Forced Migration and Mental Health: Prolonged Interna Displacement, Return Migration and Resilience. International Health, 5(1), 19-23. Doi:10.1093/inthealth/ihs014

Silove, D.; Ventevogel, P. \& Rees, S. (2017). The Contemporary Refugee Crisis: An Overview of Mental Health Challenges. World Psychiatry, 16(2), 130-139. Doi:10.1002/wps.20438

Smith, S. (2007). Poetry and Displacement. Oxford University Press.

Tebeje, Alemu. (2016). Greetings to the People of Europe!. Modern Poetry in Translation. https://modernpoetryintranslation.com/poem/greetings-to-the-people-of-europe/.

United Nations High Commissioner for Refugees. (n.d.). Figures at a Glance in Malaysia. Retrieved 31 May 2019, from UNHCR website: https://www.unhcr.org/enmy/figures-at-a-glance-in-malaysia.html 